\title{
Improving Water Supply Capacity of Drainage Systems at Humid Areas in the Changing Climate
}

\author{
Lyudmyla Kuzmych ${ }^{1}$, Galyna Voropay ${ }^{1}$, Nelya Moleshcha ${ }^{1}$, Olena \\ Babitska ${ }^{1}$ \\ ${ }^{1}$ Institute of Water Problems and Land Reclamation of the National Academy of Agrarian Sciences of \\ Ukraine; 37 Vasylkivska Str., 03022, Kyiv, Ukraine, e-mail: kuzmychlyudmyla@gmail.com \\ (corresponding author)
}

(Received 06 April 2021; revised 26 July 2021)

\begin{abstract}
The paper focuses on research on improving the water supply of drainage systems of humid areas in the context of climate change. The aim of the research is to elaborate on the ways for increasing the available water supply of drainage systems and restoring active water regulation on reclaimed lands in a changing climate.

The paper presents the results of the research on improving the available water supply of drainage systems in the humid zone of Ukraine in a changing climate. It was specified in the face of increasing water scarcity providing the optimal water regime regulation on drained lands is possible due to the increase in the available water supply of drainage systems. It can be achieved thanks to the accumulating capacity of reclaimed areas, namely usage of free soil capacity of the aeration zone and open canals, accumulation of water reserve volumes in storage tanks due to the accumulation of surface and drainage runoff.

Taking into account the design features of different types of drainage systems, existing water management technologies, characteristics of water sources and their close proximity to the drainage systems, the technological schemes of water intake from rivers and reservoirs, and its supply to the drained areas for irrigation needs were developed. In a face of increasing water scarcity, it is also expedient to apply resource-saving technologies to control the available water supply for crops.
\end{abstract}

Key words: reclaimed land, drainage system, climate change, water supply, crop

\section{Introduction}

Drainage reclamation in the humid zone is an important factor in sustainable agricultural production, and the economic, environmental, and social stability of the region largely depends on the efficiency of drainage systems. At the same time, modern climate change is accompanied by deteriorating conditions of natural moisture

(C) 2021 Institute of Hydro-Engineering of the Polish Academy of Sciences. This is an open access article licensed under the Creative Commons Attribution-NonCommercial-NoDerivs License (http://creativecommons.org/licenses/by-nc-nd/3.0/). 
supply, including and reclaimed lands of the humid zone, and form new conditions for growing crops, which, accordingly, transforms the role of drainage systems (Romashchenko et al 2019, Romashchenko 2019a, Romashchenko 2019b, Romashchenko et al 2020).

Given the tendency to further increase the aridity of the climate in the world and, in particular, in Ukraine and, accordingly, the deterioration of natural moisture in most parts of its territory and the formation in the humid zone of conditions not only waterlogging but also moisture deficit, the need for the role of drainage systems in sustainable agriculture (Babich et al 2017, Korobiichuk et al 2017, Korobiichuk et al 2019, Rokochinskiy et al 2019, Rokochinskiy et al 2020, Korobiichuk et al 2020).

Due to changes in climatic conditions in the humid zone, the value and importance of agricultural land in the region are growing, as due to warming, the area of cultivation of thermophilic crops (sunflower, corn, soybeans) is shifted from traditional cultivation zones to the north and west. However, the deterioration of natural moisture conditions necessitates its artificial improvement (Irrigation and drainage in Ukraine for the period up to 2030 (2019), Datsko 2016, Yatsyk et al 2009, Romashchenko 2019b).

Thus, today increasing the water supply of drainage systems and restoring their effective use in the regime of active water regulation is becoming a key condition for the implementation of intensive technologies for growing crops and minimizing the impact of climate change on agricultural efficiency in humid regions.

The aim of the research is to develop directions for increasing the water supply of drainage systems of the humid zone for the restoration of active water regulation on drained lands in the conditions of climate change.

\section{Methods and Techniques}

The research methodology is based on the generalization of scientific knowledge and conducting experimental research on the water supply of drainage systems of the humid zone and the water storage capacity of their territories, taking into account the objectives and requirements of Water Framework Directive 2000/60/EC of the European Parliament and of the Council on establishing a framework for Community action in the field of water policy.

Researchers conducted in the area of the Left Bank Forest-Steppe of Ukraine (Fig. 1) at the reclaimed area of the drainage and humidification system "Romen" (Sumy region), include determination of meteorological factors, dynamics of groundwater level, level of surface water and volume of water in the source of water accumulation for humidification.

Measurements of the current groundwater level at the reclaimed area are carried out every decade (ten days), and in the periods after the selection additional measurements are provided, the number and frequency of which depend on the intensity of the fall. 


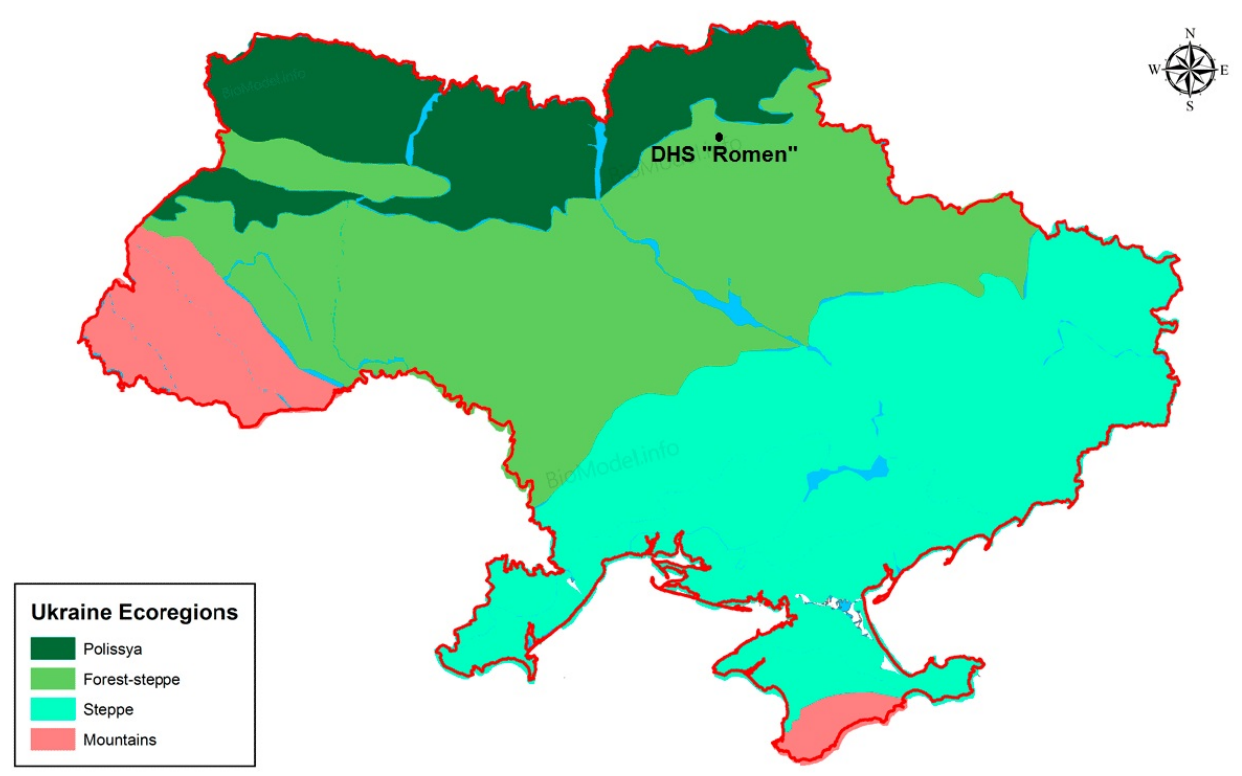

Fig. 1. Scheme of Ukraine ecoregions with the layout of the drainage and humidification system "Romen" (Sumy region)

The design of the drainage and humidification system "Romen" (Fig. 2) includes a channel lock, opens and closes the control network, storage quality. The storage tank is built on the site of antiquity, its length is $500 \mathrm{~m}$ and width $22 \mathrm{~m}$. The volume of the tank is $50000 \mathrm{~m}^{3}$, including the volume of the compartment for the accumulation of drainage water is $12000 \mathrm{~m}^{3}$. Replenishment of the storage tank is carried out through the collection of drainage and discharge water and water supply by gravity from the registration channel (Romen River). Water supply to the call from the tank is also gravity. The use of pooled waters from the Karabutiv Reservoir, which is arranged within the reclamation system, is also envisaged for carrying out retaliatory measures.

\section{Results and Discussion}

To develop conceptual directions for improving the water supply of drainage systems, the generalized results of many years of scientific research conducted by scientists of the Institute of Water Problems and Land Reclamation of the National Academy of Agrarian Sciences of Ukraine were used. The creation of guaranteed volumes of water to regulate the water regime on drained lands is based on the use of the accumulation capacity of reclaimed areas and resources of surface water bodies, inland water bodies and groundwater bodies located outside the drainage systems.

The main conceptual direction of the complex of engineering and technical measures to increase the water content of reclaimed areas, moisture accumulation during periods of high rainfall is the use of water storage capacity of reclamation systems (Fig. 3). 


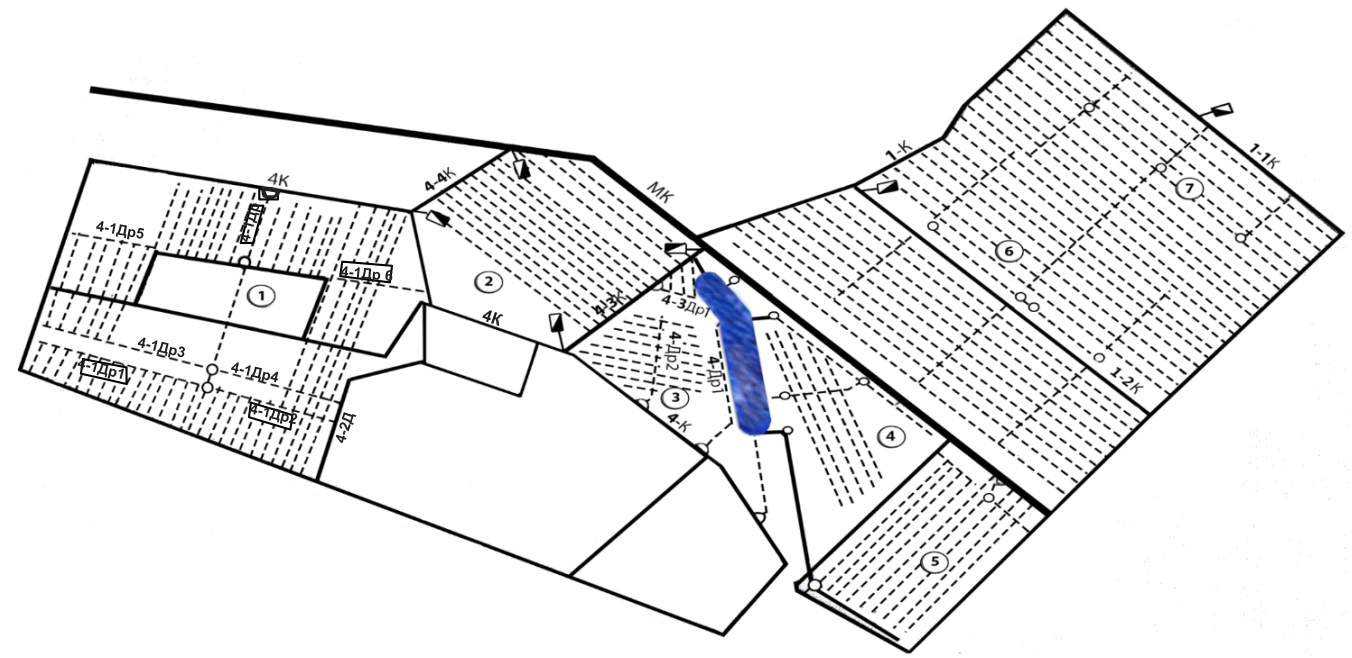

Fig. 2. Scheme of the drainage and humidification system "Romen":

1 - drainage by material drainage with irrigation; 2 - drainage by a steady drainage with ground moistening by means of sluices-regulators; $3,4,7$ - drainage with traditional pottery drainage; 5 - pottery drainage with soil moistening; 6 - drainage by potter's drainage with the automated system of water supply in a drain mouth at cyclic regulation

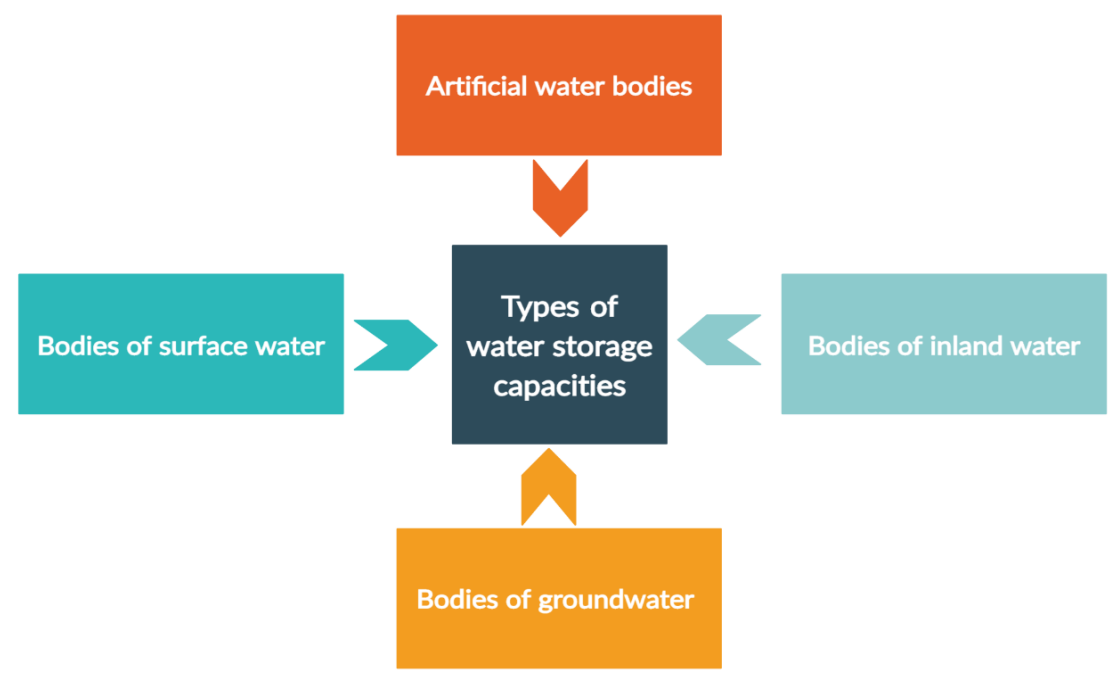

Fig. 3. Basic principles of formation (creation) of water storage capacities to improve the water supply of reclaimed areas

In addition, the reclamation system, which is located in the floodplain of the river, in the presence of embankment dams and drainage control structures can be used to accumulate water and reduce the peak of floods in a controlled mode (Water Frame- 
work Directive 2000, Water Framework Directive review by the European Commission 2012).

As the results of the research have shown (Recommendations for the use of water accumulation capacity of polder reclamation systems in the Transcarpathian region during floods and flooding of adjacent areas 2009, Rokochinskiy et al 2019, Rokochinskiy et al 2020), in modern conditions the most effective and economical technological method of regulating the water regime on drained lands is the accumulation of local drainage runoff. Since the drainage runoff in the flow item of the water balance has a significant share and by volume is more than $50 \%$ of the total water consumption of crops, the determination of its value is of great practical importance not only for drainage design but also for bilateral regulation of reclaimed water regime soils and determination of estimated volumes of water for moisturizing measures (Conducting a spatial analysis of changes in the water regime of basins of surface water bodies in Ukraine due to climate change 2019, Voropay et al 2019, Yatsyk et al 2016).

Drainage runoff, that is excess moisture that infiltrates through the root layer of the soil and is discharged by regulatory channels (drains), pre-sowing, sowing, and summer (vegetation) periods can accumulate in the storage tanks of reclamation systems. The basis for calculating the parameters of these tanks is to determine the modulus of drainage runoff in the most stressful periods of drainage (spring, pre-sowing; summer flood) and the catchment area (or drained module). The calculations of the parameters of water storage tanks take into account the peculiarities of the natural and climatic conditions of the humid area and the provision of precipitation (Yatsyk et al 2016).

Given the shortage of local drainage and surface runoff for soil moisture on drained lands, there is an urgent need to increase the water supply of reclaimed areas by collecting and supplying to reclamation systems additional volumes of water from existing reservoirs, rivers, ponds, lakes, located within and outside systems.

Taking into account the design features of different types of reclamation systems in the humid area, existing water management technologies, characteristics of water bodies and their location in relation to the systems developed unified technological schemes of water intake from rivers and reservoirs and its supply to moisten drained soils.

The first version of water supply from the reservoir to the drainage network of the reclamation system through the transport channel with storage tanks provides the creation of guaranteed volumes of water for wetting on large areas of drained land. Depending on the length of the transport channel, the size of the required reserve water volumes, and the area of drained lands on which the groundwater is planned, one or more storage tanks may be placed along the route of the channel. This design solution minimizes the intake of water from reservoirs without violating the technological needs and requirements of water users of water bodies.

In the second version technological capacity of water intake and accumulation from water sources located outside the reclamation system, the transport channels act 
as accumulators of reserve volumes of water for further use to moisten drained soils in dry periods.

The reclaimed territory with a cascade of accumulating tanks is divided into separate autonomous modular plots, the number, and area of which are determined by the relief conditions, the configuration of the array, technological, technical, and environmental requirements of land users.

As practice has shown, the proposed engineering and technological solutions allow to accumulate significant amounts of water and increase the water content of areas within reclamation systems. The implementation of these solutions should be carried out, first of all, on those systems where the level of existing engineering infrastructure and embedded design and technological solutions minimizes capital costs for the construction of new embankment dams, water intake and discharge hydraulic structures, as well as additional pumping stations. reservoirs (Land reclamation 2015).

The technology of accumulation of water volumes and drainage runoff has been tested at pilot facilities of drainage systems in Chernihiv and Rivne (2011-2013) and Sumy (2014-2015) regions (Yatsyk et al 2016).

The application of this technology at the pilot sites of Chernihiv and Rivne regions ensured the accumulation of water in the soil during the growing season in volumes from 780 to $1600 \mathrm{~m}^{3} /$ ha and the optimal water regime of drained soils in the range of $0.70-1.20 \mathrm{~m}$.

The results of testing at the pilot facilities of Sumy region show that in terms of average rainfall in 2015 (57\%) the actual volume of water for humidification was 21.45 thousand $\mathrm{m}^{3}$, and the potential volume of accumulation of drainage runoff from the area $14.9 \mathrm{ha}-46.3$ thousand $\mathrm{m}^{3}$, which is sufficient to moisten the territory of the pilot areas during the growing season. Of the possible potential volume of drainage runoff accumulation in the vegetation period, 3.3 thousand $\mathrm{m}^{3}$ was used to fill the storage tank, while the estimated average value of the drainage runoff module was $0.21 \mathrm{l} / \mathrm{s}$ per $1 \mathrm{ha}$, and the drainage runoff volume was $270.3 \mathrm{~m}^{3} /$ day from an area of $14.9 \mathrm{ha}$, and the values of these indicators, which were determined experimentally, respectively $-0.22 \mathrm{l} / \mathrm{s}$ from 1 ha and $283.2 \mathrm{~m}^{3} /$ day (Yatsyk et al 2015).

Research on the water supply of reclaimed areas in 2019 was conducted in the area of the Left Bank Forest-Steppe of Ukraine at the drainage and humidification system "Romen" (Sumy region). Grown crops - paisa, amaranth, and fodder beans.

During the vegetation period of $2019,219.9 \mathrm{~mm}$ of precipitation fell, which is $102.4 \mathrm{~mm}$ less than the long-term norm (87\% precipitation), and their amount was less than the norm in all months of the vegetation period, except May (more than the norm for $23.1 \mathrm{~mm}$ ). The average monthly air temperature was lower than the norm in all months except June (exceeding the norm by $1.3^{\circ} \mathrm{C}$ ). The average monthly air temperature during the growing season was lower by $1.0^{\circ} \mathrm{C}$ compared to the long-term indicator and was $+15.3^{\circ} \mathrm{C}$.

The results of researches of the dynamics of groundwater level are shown in the Table 1 and at the Figure 4. 
Table 1. Groundwater level at the reclaimed area of the drainage and humidification system "Romen", cm from the ground surface (2019)

\begin{tabular}{|l|c|c|c|c|c|c|c|c|}
\hline \multirow{2}{*}{ Month } & \multicolumn{7}{|c|}{ The date of measurement } & \multirow{2}{*}{ Average } \\
\cline { 2 - 9 } & 1 & 5 & 10 & 15 & 20 & 25 & 30 & \\
\hline April & 48 & 50 & 57 & 60 & 65 & 68 & 73 & 60 \\
\hline May & 80 & 80 & 85 & 85 & 90 & 90 & 110 & 88 \\
\hline June & 120 & 125 & 130 & 135 & 135 & 145 & 150 & 134 \\
\hline July & 150 & 155 & 155 & 158 & 160 & 170 & 175 & 160 \\
\hline August & 180 & 185 & 185 & 190 & 195 & 200 & 200 & 190 \\
\hline September & 200 & 200 & 200 & 200 & 200 & 200 & 200 & 200 \\
\hline
\end{tabular}

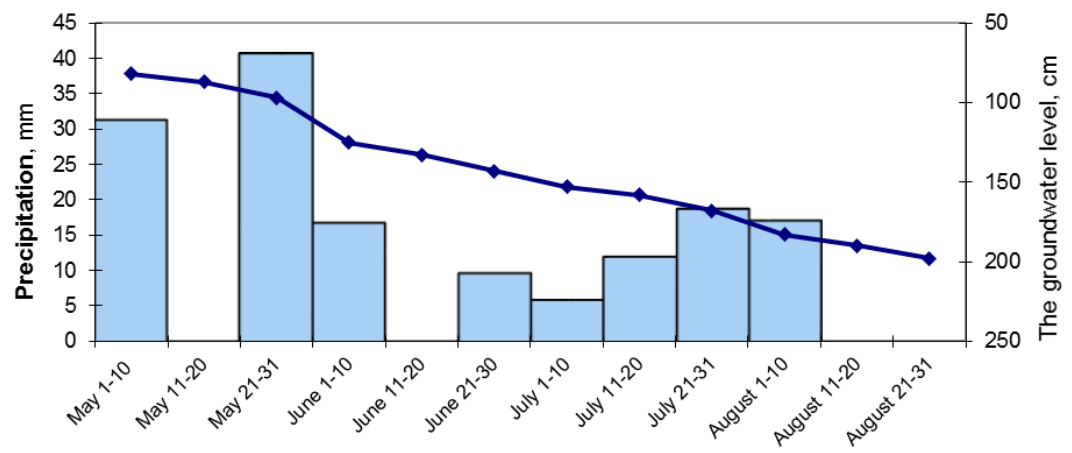

Fig. 4. Dynamics of precipitation and the groundwater levels at the reclaimed area of the drainage and humidification system "Romen" (2019)

In the spring, the groundwater level ensured the passage of agricultural machinery, pre-sowing tillage, and sowing of crops, but in the future, the recommended groundwater levels were not provided.

This is explained by the fact that in the summer the amount of precipitation was less than normal in all months of the growing season. In such conditions and in the absence of spring floods, it was impossible to accumulate in the storage tank enough water for humidification. The levels and volume of water in the storage tank are shown in the Table 2.

The results of the research show that the need for moisturizing measures falls on the period from July to September, but the filling of the tank with water for this period was insufficient for its supply to the experimental sites.

The next option is to attract additional sources of water for humidification from the Karabutiv Reservoir, which is arranged at the drainage and humidification system "Romen" to accumulate water during high water periods and supply it for humidification in arid periods. The volumes of water in the Karabutiv Reservoir in 2019 are shown in the Table 3. 
Table 2. Levels and volume of water in the storage tank in the growing season, drainage and humidification system "Romen" (2019)

\begin{tabular}{|l|c|c|}
\hline Month & $\begin{array}{c}\text { Water level } \\
{[\mathrm{m}]}\end{array}$ & $\begin{array}{c}\text { Water volume } \\
{\left[\mathrm{m}^{3}\right]}\end{array}$ \\
\hline April & 3.6 & 39600 \\
\hline May & 3.6 & 39000 \\
\hline June & 3.0 & 33000 \\
\hline July & 2.2 & 24200 \\
\hline August & 1.2 & 13200 \\
\hline September & 1.1 & 12000 \\
\hline
\end{tabular}

Table 3. The volumes of water in the Karabutiv Reservoir (Sumy region, 2019)

\begin{tabular}{|c|c|c|c|}
\hline Month & $\begin{array}{c}\text { Water level from the 0th mark } \\
\text { sm }\end{array}$ & $\begin{array}{c}\text { The volume of water } \\
{\left[\text { million } \mathrm{m}^{3}\right]}\end{array}$ & Note \\
\hline 01.01 & -60 & 10.19 & \\
\hline 20.01 & -60 & 10.19 & \\
\hline 01.02 & -60 & 10.19 & \\
\hline 20.02 & -52 & 10.51 & \\
\hline 01.03 & -45 & 10.64 & \\
\hline 20.03 & -43 & 10.93 & \\
\hline 01.04 & -43 & 10.93 & \\
\hline 20.04 & -43 & 10.93 & \\
\hline 01.05 & -43 & 10.93 & \\
\hline 20.05 & -43 & 10.93 & \\
\hline 01.06 & -45 & 10.64 & \\
\hline 20.06 & -50 & 10.59 & \\
\hline 26.06 & -60 & 10.19 & The mine is open at 18.00 \\
\hline 29.06 & -67 & 9.95 & The mine is closed at 8.00 \\
\hline 03.07 & -69 & 9.84 & \\
\hline 10.07 & -72 & 9.72 & \\
\hline 17.07 & -73 & 9.66 & \\
\hline 24.07 & -76 & 9.56 & \\
\hline 31.07 & -79 & 9.44 & \\
\hline 07.08 & -82 & 9.32 & \\
\hline 13.08 & -84 & 9.20 & The mine is open at 13.00 \\
\hline 14.08 & -85 & 9.18 & \\
\hline 16.08 & -89 & 9.08 & The mine is closed at 8.00 \\
\hline 21.08 & -90 & 9.04 & \\
\hline 30.08 & -100 & 8.64 & \\
\hline 10.09 & -105 & 8.43 & \\
\hline 20.09 & -110 & & \\
\hline & & & \\
\hline
\end{tabular}

Karabutiv Reservoir has a water surface area at the normal water level (NWL) of $5.02 \mathrm{~km}^{2}$ (the mark of NWL is $145.5 \mathrm{~m}$ ), the total capacity of 12.97 million $\mathrm{m}^{3}$, and a useful capacity of 11.97 million $\mathrm{m}^{3}$. As can be seen from the Table 7 , the volume of water in the reservoir in 2019 ranges from 10.93 million $\mathrm{m}^{2}$ to 8.24 million $\mathrm{m}^{2}$. Therefore, the filling of the reservoir to the level of useful volume was not achieved during the growing season. 
Moisturizing measures were carried out in two periods: from 26 to 29 June and from 13 to 16 August. The volume of water supplied for moistening was 0.24 million $\mathrm{m}^{3}$ and 0.12 million $\mathrm{m}^{3}$, respectively, but they were insufficient to replenish the moisture reserves of the active layer of the soil and to provide the necessary water-air regime for the cultivated crops.

In general, the possibilities of the available water bodies (storage tank, Karabutiv Reservoir), which are located at the reclaimed lands of the drainage and humidification system "Romen", were not used due to their insufficient filling with water.

The results of researches of the dynamics of the groundwater levels at the reclaimed area of the drainage and humidification system "Romen" during the season of the vegetation in 2020 are given in the Table 4 and at the Figure 5.

Table 4. Groundwater level at the reclaimed area of the drainage and humidification system "Romen", cm from the ground surface (2020)

\begin{tabular}{|l|c|c|c|c|c|c|c|c|}
\hline \multirow{2}{*}{ Month } & \multicolumn{7}{|c|}{ The date of measurement } & \multirow{2}{*}{ Average } \\
\cline { 2 - 9 } & 1 & 5 & 10 & 15 & 20 & 25 & 30 & \\
\hline April & 55 & 60 & 62 & 65 & 65 & 70 & 75 & 65 \\
\hline May & 75 & 75 & 80 & 80 & 85 & 90 & 95 & 83 \\
\hline June & 100 & 115 & 120 & 130 & 135 & 135 & 1450 & 125 \\
\hline July & 140 & 145 & 1505 & 155 & 160 & 170 & 175 & 157 \\
\hline August & 180 & 185 & 190 & 190 & 195 & 200 & 200 & 191 \\
\hline September & 200 & 200 & 200 & 200 & 200 & 200 & 200 & 200 \\
\hline
\end{tabular}

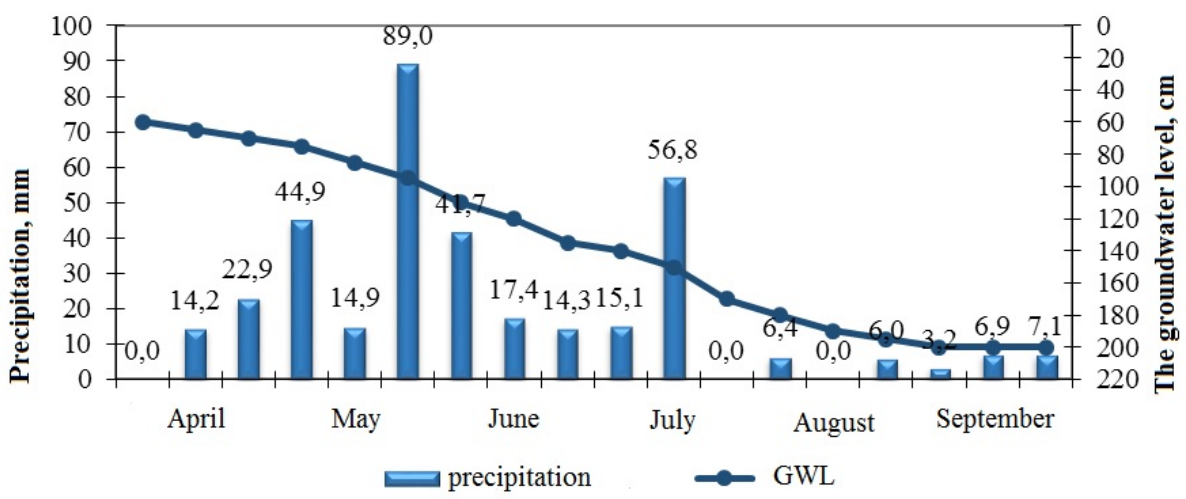

Fig. 5. Dynamics of precipitation and the groundwater levels at the reclaimed area of the drainage and humidification system "Romen" (2020)

In the vegetation period of 2020, the actual groundwater level was on average: in April - $65 \mathrm{~cm}$; May $-83 \mathrm{~cm}$; June $-125 \mathrm{~cm}$; July $-157 \mathrm{~cm}$; August $-191 \mathrm{~cm}$; September $-200 \mathrm{~cm}$ from the surface. 
In the spring, the groundwater level provided the passage of agricultural machinery, pre-sowing tillage, and sowing of crops, but in the future, the recommended groundwater levels were not provided.

Ensuring optimal humidity and, consequently, moisture reserves, according to the phases of development of the studied crops on the drainage and humidification system "Romen" was provided in critical periods of growing paise, amaranth, and fodder beans (by the end of June), which was achieved mainly by accumulating precipitation in the root layers of soil. Due to insufficient filling of available water resources with water resources (storage tank, Karabutiv Reservoir), which are located in the area of reclaimed lands of the drainage and humidification system "Romen", water supply for moistening of cultivated crops was not carried out.

The results of the research show that in the absence of spring floods it was impossible to accumulate in the storage tank enough water to moisten both due to drainage runoff and water supply from the main channel. The levels and volume of water in the storage tank in the vegetation period of 2020 are given in the Table 5.

Table 5. Levels and volume of water in the storage tank in the growing season, drainage and humidification system "Romen" (2020)

\begin{tabular}{|l|c|c|}
\hline Month & $\begin{array}{c}\text { Water level } \\
{[\mathrm{m}]}\end{array}$ & $\begin{array}{c}\text { Water volume } \\
{\left[\mathrm{m}^{3}\right]}\end{array}$ \\
\hline April & 3.4 & 37400 \\
\hline May & 3.5 & 38500 \\
\hline June & 3.2 & 33000 \\
\hline July & 2.1 & 23100 \\
\hline August & 1.1 & 12100 \\
\hline September & 1.0 & 11000 \\
\hline
\end{tabular}

The results of research of the dynamics of water volume in the Karabutiv Reservoir in the period 2019-2020 are shown at the Figure 6.

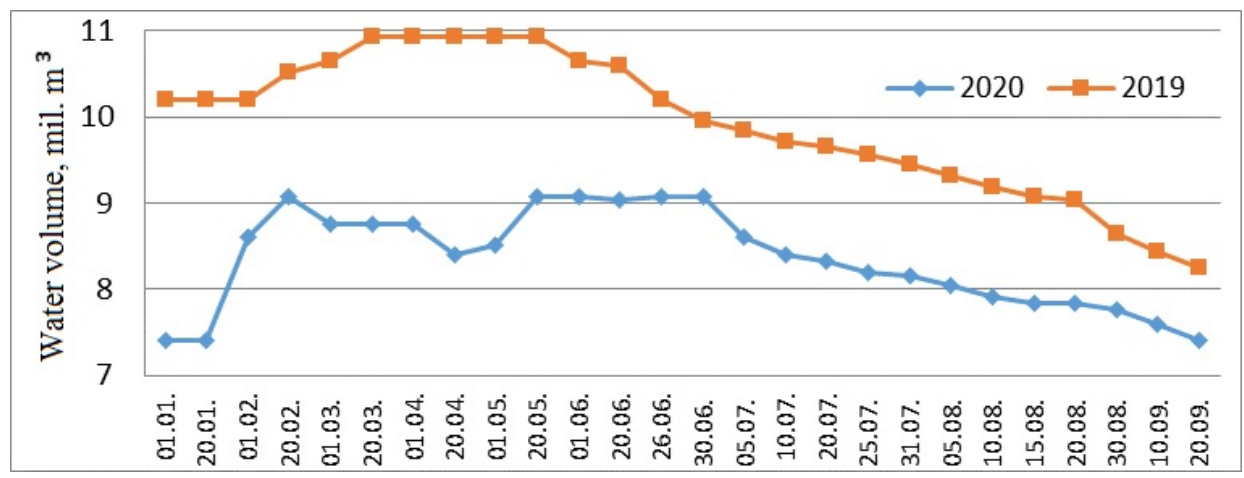

Fig. 6. Dynamics of water volume in Karabutiv Reservoir in the period 2019-2020 
The volume of water in the Karabutiv Reservoir in 2020 ranged from 9.08 million $\mathrm{m}^{3}$ to 7.40 million $\mathrm{m}^{3}$, and compared to 2019 was even smaller. During the research period, the filling of the reservoir to the level of useful volume was not achieved, so it was impossible to carry out wetting measures.

\section{Conclusions}

For the forest-steppe ecoregions in the conditions of climate change, a growing shortage of water resources, active regulation on drained lands is possible due to increased water supply of reclamation systems, which can be achieved through the use of storage capacity of reclaimed areas by using free soil capacity of aeration zones and open canals, creating reserve channels in accumulating tanks due to the accumulation of surface and drainage runoff.

In the period 2019-2020, ensuring optimal moisture and, consequently, moisture reserves of the soil according to the phases of development of the studied crops at the drainage and humidification system "Romen" (Sumy region, Ukraine) was provided in critical periods of growing paise, amaranth and fodder beans and was achieved mainly through the accumulation of precipitation in the root layer. Due to insufficient filling of available water resources with water resources (storage tank, Karabutiv Reservoir), which are located in the area of the reclaimed lands of the drainage and humidification system "Romen", water supply for moistening of cultivated crops was not carried out.

Therefore, given the shortage of local drainage and surface runoff, it is necessary to provide for ground wetting on drained lands due to the accumulation of water from water bodies located outside the reclamation system. In such conditions, it is also advisable to use resource-saving technologies for moisture management of crops, including surface irrigation with small irrigation and irrigation standards, which are developed for the humid areas according to research at reclamation systems of Transcarpathian, Rivne, and Sumy regions of Ukraine.

\section{References}

Babich V., Dovbenko V., Kuzmych L., Dovbenko T. (2017) Estimation of flexures of the reinforced concrete elements according to the National Ukrainian \& European standards, MATEC Web of Conferences, Vol. 116, 10 July 2017, Article number 02005.

Conducting a spatial analysis of changes in the water regime of basins of surface water bodies in Ukraine due to climate change (2019) Final report on the results of research [Electronic resource] - Access mode: http://uhmi.org.ua/project/rvndr/avr.pdf.

Datsko L. V. (2016) Modern agricultural use of lands of the humid zone of Ukraine, Reclamation and water management, $\mathbf{1 0 3}, 41-47$.

Irrigation and drainage strategy in Ukraine for the period up to 2030 (2019) Approved by the Cabinet of Ministers of Ukraine, No. 688-r.

Korobiichuk I., Drevetsky V., Kuzmych L., Kovela I. (2020) The method of multy-criteria parametric optimization, Advances in Intelligent Systems and Computing, 1140, Automation 2020: Towards Industry of the Future, 87-97, doi.org/10.1007/978-3-030-40971-5; available at: https://link.springer.com/chapter/10.1007/978-3-030-40971-5_9. 
Korobiichuk I., Kuzmych L., Kvasnikov V. (2019) The system of the assessment of a residual resource of complex technical structures, MECHATRONICS 2019: Recent Advances Towards Industry 4.0, 350-357, https://doi.org/10.1007/978-3-030-29993-4_43.

Korobiichuk I., Kuzmych L., Kvasnikov V., Nowak P. (2017) The use of remote ground sensing data for assessment of environmental and crop conditions of the reclaimed land, Advances in Intelligent Systems and Computing (AISC), 550, ICA 2017: Automation 2017, 418-424, DOI: 10.1007/978-3-319-54042-9_39.

Land reclamation (systematics, prospects, innovations) (2015) Collective monograph (edited by S. A. Balyuk, M. I. Romashchenko, R. S. Truskavetskiy). Kherson: Grin D.S., 668 p.

Recommendations for the use of water accumulation capacity of polder reclamation systems in the Transcarpathian region during floods and flooding of adjacent areas (2009) Report, No. of state register 0109U007893, K. 2009, IWPM Funds.

Rokochinskiy A., Korobiichuk I., Kuzmych L., Volk P., Kuzmych A. (2020) The system optimization of technical, technological and construction parameters of polder systems, Advances in Intelligent Systems and Computing, 1140, Automation 2020: Towards Industry of the Future, 78-86, doi.org/10.1007/978-3-030-40971-5 - available at: https://link.springer.com/chapter/10.1007/978-3-030-40971-5_8.

Rokochinskiy A., Volk P., Kuzmych L., Turcheniuk V., Volk L., Dudnik A. (2019) Mathematical model of meteorological software for systematic flood control in the carpathian region, International Conference on Advanced Trends in Information Theory (ATIT), IEEE, 143-148.

Romashchenko M. I., Husyev Yu. V., Shatkovskyi A. P., Saidak R. V., Yatsyuk M. V., Shevchenko A. M., Matiash T. V. (2020) The impact of modern climate change on water resources and agricultural production, Land reclamation and water management, 1, 5-22.

Romashchenko M. I., Saidak R. V., Matiash T. V., Knysh V. V. (2019) Influence of climatic changes on moisture supply of the territory of Ukraine and production of agricultural products, "Water for All": dedicated to World Water Day: International. scientific-practical Conference, thesis add., Kyiv 2019, 179-180.

Romashchenko M. I. (2019a) Development of scenarios of climate change in Ukraine in the medium and long term using data from global and regional models, [Electronic resource], Access mode: http: // uhmi.org.ua/project/rvndr/climate.pdf.

Romashchenko M. I., (2019b) The impact of climate change on the state of Ukraine's water resources, Proceedings of the International scientific-practical conference dedicated to the World Water Day (water for all), March 21, 2019, Kyiv, 11-12.

Voropay G. V., Yatsyk M. V., Mozol N. V. (2019) Current state and prospects of development of drainage reclamation in the conditions of climate change, Reclamation and water management, 2, 31-39.

Water Framework Directive 2000/60/EC (2000) https://eur-lex.europa.eu/legal-content/EN/TXT/?uri=celex\%3A32000L0060.

Water Framework Directive review by the European Commission (2012) http://eur-lex.europa.eu/legal-content/EN/TXT/PDF/?uri=CELEX:52012DC0670\&from=EN.

Yatsyk M. V., Voropay G. V., Moleshcha N. B. (2016) Improving water supply of reclamation systems of the humid zone, Reclamation and water management, 103, 63-68.

Yatsyk M. V., Voropay G. V., Topolnuk T. I., Shushkevich Yu. A. (2015) Methodological bases of increase of water supply of reclamation systems by creation of accumulating capacities, Land reclamation and water management, 102, 54-58. 